\title{
Protein oxidation injury occurs during pediatric cardiopulmonary bypass
}

\author{
Meredith L. Sheil, MBBS, FRACP, ${ }^{a, b}$ Catherine Luxford, PhD, ${ }^{c}$ Michael J. Davies, DPhil, ${ }^{c}$ Jennifer K. Peat, PhD, ${ }^{b}$ \\ Graham Nunn, MBBS, FACS, ${ }^{a}$ and David S. Celermajer, MBBS, FRACP, PhD ${ }^{a, c, d}$
}

From the Adolph Basser Cardiac Institute, The Children's Hospital at Westmead, Sydney, ${ }^{a}$ Discipline of Pediatrics and Child Health, University of Sydney, ${ }^{\mathrm{b}}$ The Heart Research Institute, Sydney, ${ }^{c}$ and Department of Medicine, University of Sydney, Australia. $^{\mathrm{d}}$

Dr Sheil is funded by The National Heart Foundation, Australia, and The Children's Hospital Fund; Dr Davies is funded by the Australian Research Council.

Received for publication Nov 29, 2004; revisions received Feb 15, 2005; accepted for publication March 31, 2005.

Address for reprints: Meredith L. Sheil, MBBS, FACS, Adolph Basser Cardiac Institute, The Children's Hospital at Westmead, Cnr Hawkesbury Rd and Hainsworth St, Locked Bag 4001, Westmead, NSW, Australia 2145 (E-mail: Meredits@chw.edu.au).

J Thorac Cardiovasc Surg 2005;130:1054-61 $0022-5223 / \$ 30.00$

Copyright (c) 2005 by The American Association for Thoracic Surgery

doi:10.1016/j.jtcvs.2005.03.048
Objective: Proteins are the major effectors of biological structure and function. Oxidation-induced changes to protein structure can critically impair protein function, with important pathologic consequences. This study was undertaken to examine whether oxidation-induced changes to protein structure occur during pediatric cardiopulmonary bypass and to examine the association with postoperative outcome.

Methods: Elevation of the 3,4-dihydroxyphenylalanine content of a protein relative to its native tyrosine content indicates structural damage due to oxidation. Protein 3,4-dihydroxyphenylalanine/native tyrosine ratios were measured before surgery and up to 6 hours after institution of cardiopulmonary bypass in 24 children undergoing repair of congenital heart disease, who were prospectively selected to form a cyanotic and comparable acyanotic control group. Results were correlated with perioperative variables and postoperative outcomes.

Results: Elevation of protein 3,4-dihydroxyphenylalanine/tyrosine ratios above baseline $(0.48 \mathrm{mmol} / \mathrm{mol}$ [SD, $0.11 \mathrm{mmol} / \mathrm{mol}]$ vs $0.36 \mathrm{mmol} / \mathrm{mol}[\mathrm{SD}, 0.13 \mathrm{mmol} / \mathrm{mol}] ; P=$ .001 ) occurred within 30 minutes of initiating cardiopulmonary bypass in cyanotic but not in acyanotic children and correlated inversely with preoperative arterial oxygen saturation $(R=-0.52 ; P=.03)$. Protein 3,4-dihydroxyphenylalanine/tyrosine ratios were also increased above baseline at 120 minutes $(0.44 \mathrm{mmol} / \mathrm{mol}$ [SD, 0.12 $\mathrm{mmol} / \mathrm{mol}] ; P=.007)$ and 180 minutes $(0.40 \mathrm{mmol} / \mathrm{mol}[\mathrm{SD}, 0.14 \mathrm{mmol} / \mathrm{mol}]$; $P=.01)$ after the institution of cardiopulmonary bypass in children who underwent prolonged procedures. Elevation of 3,4-dihydroxyphenylalanine/tyrosine during prolonged procedures was associated with postoperative arrhythmias and the need for increased inotropic support $(P=.001)$.

Conclusions: Oxidative injury to proteins occurs during pediatric cardiopulmonary bypass. Cyanotic children are most at risk, particularly those undergoing prolonged procedures, in whom elevation of the protein 3,4-dihydroxyphenylalanine/tyrosine ratio is associated with increased postoperative morbidity.

$\mathrm{P}$ roteins are the major effectors of the body's biological structure and function. The diverse nature of protein function critically depends on their exact conformation and pattern of folding. The pathologic implications of geneticinduced anomalies in protein structure are well recognized. Genomic anomalies, however, are not the only way in which the amino acid sequence of proteins can be disturbed. Proteins are also major targets of oxidative damage. Reactive oxygen and nitrogen species are capable of chemically altering protein structure. The amino acid tyrosine, for example (a component of virtually all proteins), is readily oxidized to the dihydroxylated species 3,4-dihydroxyphenylalanine (DOPA). ${ }^{1}$ The "replacement" of tyrosine by DOPA residues in the amino acid sequence can have a critical effect on protein function. ${ }^{2}$ Increasingly it is being recognized that oxidative 
TABLE 1. Demographic and perioperative variables

\begin{tabular}{|c|c|c|c|c|c|c|c|c|c|c|c|c|}
\hline \multirow[b]{2}{*}{ Patient no. } & \multirow[b]{2}{*}{ Operation } & \multirow{2}{*}{$\begin{array}{l}\text { Age } \\
(\mathrm{mo})\end{array}$} & \multirow{2}{*}{$\begin{array}{l}\text { BSA } \\
\left(\mathrm{m}^{2}\right)\end{array}$} & \multirow{2}{*}{$\begin{array}{l}\text { Sat } \\
(\%)\end{array}$} & \multirow{2}{*}{$\begin{array}{l}\text { CPB } \\
(\min )\end{array}$} & \multirow{2}{*}{$\begin{array}{c}\text { XCT } \\
(\min )\end{array}$} & \multicolumn{4}{|c|}{ DOPA/tyrosine (mmol/mol) } & \multirow[b]{2}{*}{ A } & \multirow{2}{*}{$\begin{array}{l}\text { Inotropic } \\
\text { support } \\
\text { (d) }\end{array}$} \\
\hline & & & & & & & $3 \mathrm{~min}$ & $30 \mathrm{~min}$ & $120 \mathrm{~min}$ & $180 \mathrm{~min}$ & & \\
\hline \multicolumn{13}{|l|}{$\begin{array}{r}\text { Acyanotic } \\
\text { patients }\end{array}$} \\
\hline 1 & Close secundum ASD & 13 & 0.5 & 98 & 35 & 8 & 0.23 & 0.34 & 0.27 & 0.34 & & 0.5 \\
\hline 2 & Close secundum ASD & 138 & 1.7 & 98 & 40 & 19 & 0.27 & 0.28 & 0.30 & 0.28 & & 0.9 \\
\hline 3 & $\begin{array}{l}\text { Close primum ASD, repair } \\
\text { cleft mitral valve }\end{array}$ & 18 & 0.5 & 98 & 54 & 44 & 0.18 & 0.27 & 0.23 & 0.18 & NB & 2.6 \\
\hline 4 & $\begin{array}{l}\text { Close primum ASD, repair } \\
\text { cleft mitral valve }\end{array}$ & 82 & 0.8 & 97 & 56 & 33 & 0.36 & 0.27 & 0.33 & 0.31 & & 0.7 \\
\hline 5 & $\begin{array}{l}\text { Repair acyanotic } \\
\text { tetralogy of Fallot }\end{array}$ & 4 & 0.3 & 100 & 72 & 44 & 0.50 & 0.43 & 0.47 & 0.45 & & 1.6 \\
\hline 6 & $\begin{array}{l}\text { Replace RV to PA } \\
\text { conduit, augment right } \\
\text { PA }\end{array}$ & 17 & 0.4 & 97 & 104 & 0 & 0.12 & 0.16 & 0.16 & 0.15 & & 0.7 \\
\hline 7 & Repair PAPVD & 3.5 & 0.2 & 95 & 107 & 58 & 0.32 & 0.34 & 0.34 & 0.29 & JB & 6.9 \\
\hline 8 & Replace RV to PA conduit & 47 & 0.7 & 95 & 125 & 0 & 0.56 & 0.51 & 0.52 & 0.41 & $J B$ & 2.7 \\
\hline 9 & Replace mitral valve & 151 & 1 & 99 & 127 & 83 & 0.46 & 0.55 & 0.46 & 0.46 & & 1.2 \\
\hline 10 & $\begin{array}{l}\text { Augment bilateral PA } \\
\text { stenosis }\end{array}$ & 13 & 0.4 & 97 & 139 & 0 & 0.30 & 0.32 & 0.34 & 0.41 & & 2.5 \\
\hline 11 & $\begin{array}{l}\text { Repair cleft mitral valve } \\
\text { with severe } \\
\text { regurgitation }\end{array}$ & 15 & 0.4 & 98 & 177 & 57 & 0.53 & 0.54 & 0.46 & 0.43 & 2nd HB & 9.9 \\
\hline 12 & $\begin{array}{l}\text { Neonatal Marfan } \\
\text { syndrome-graft repair } \\
\text { aortic root }\end{array}$ & 37 & 0.6 & 97 & 200 & 174 & 0.51 & 0.60 & 0.83 & 0.75 & JET & Died \\
\hline \multicolumn{13}{|l|}{$\begin{array}{l}\text { Cyanotic } \\
\text { patients }\end{array}$} \\
\hline 13 & $\begin{array}{l}\text { Close ASD, ligate central } \\
\text { shunt }\end{array}$ & 33 & 0.5 & 82 & 62 & 22 & 0.30 & 0.30 & 0.32 & 0.28 & & 1.9 \\
\hline 14 & $\begin{array}{l}\text { Completion extracardiac } \\
\text { Fontan }\end{array}$ & 52 & 0.7 & 81 & 63 & 0 & 0.30 & 0.57 & 0.18 & 0.28 & & 4.7 \\
\hline 15 & $\begin{array}{l}\text { Completion extracardiac } \\
\text { Fontan }\end{array}$ & 142 & 1.2 & 78 & 85 & 0 & 0.50 & 0.51 & 0.49 & 0.39 & & 1.8 \\
\hline 16 & $\begin{array}{l}\text { Bidirectional Glenn shunt/ } \\
\text { atrial septectomy }\end{array}$ & 33 & 0.7 & 80 & 96 & 13 & 0.61 & 0.65 & 0.52 & 0.54 & $J B$ & 7.6 \\
\hline 17 & Repair tetralogy of Fallot & 11 & 0.3 & 75 & 114 & 89 & 0.46 & 0.60 & 0.51 & 0.37 & JET & 5.7 \\
\hline 18 & $\begin{array}{l}\text { Repair truncus arteriosus } \\
\text { type } 2\end{array}$ & 1 & 0.2 & 92 & 131 & 83 & 0.25 & 0.36 & 0.36 & 0.29 & & 5.8 \\
\hline 19 & Rastelli procedure & 10 & 0.4 & 78 & 148 & 62 & 0.42 & 0.54 & 0.57 & 0.49 & JET & 4.0 \\
\hline 20 & $\begin{array}{l}\text { Close multiple VSDs, } \\
\text { deband PA }\end{array}$ & 5 & 0.2 & 73 & 150 & 89 & 0.16 & 0.42 & 0.39 & 0.20 & & 3.7 \\
\hline 21 & $\begin{array}{l}\text { Total cavopulmonary } \\
\text { connection }\end{array}$ & 174 & 1.3 & 77 & 160 & 11 & 0.36 & 0.37 & 0.45 & 0.51 & & 6.0 \\
\hline 22 & $\begin{array}{l}\text { Arterial switch, deband } \\
\text { PA, close VSD }\end{array}$ & 23 & 0.4 & 81 & 180 & 138 & 0.26 & 0.37 & 0.24 & 0.26 & & 4.8 \\
\hline 23 & Arterial switch & 0.5 & 0.2 & 65 & 192 & 74 & 0.28 & 0.45 & 0.51 & 0.47 & JET & 10.1 \\
\hline 24 & $\begin{array}{l}\text { Repair severe tetralogy of } \\
\text { Fallot }\end{array}$ & 20 & 0.4 & 80 & 268 & 63 & 0.42 & 0.53 & 0.57 & 0.57 & JET & Died \\
\hline
\end{tabular}

$B S A$, Body surface area; Sat, preoperative arterial saturation in air; $C P B$, cardiopulmonary bypass time; $X C T$, aortic root crossclamp time; $D O P A$, 3,4-dihydroxyphenylalanine; $A$, postoperative atrial arrhythmia; $A S D$, atrial septal defect; $P A$, pulmonary artery; $P A P V D$, partial anomalous pulmonary venous drainage; $R V$, right ventricle; $V S D$, ventricular septal defect; $J B$, junctional bradyarrhythmia; JET, junctional ectopic tachycardia; $N B$, nodal bradyarrhythmia; $2 n d H B$, second-degree heart block. 
modifications to proteins, much like genome-based modifications, may have important pathologic consequences. ${ }^{1-6}$

Children undergoing cardiopulmonary bypass (CPB) for the repair of congenital heart disease may be at risk of oxidative injury to the proteome. Such children, particularly those undergoing prolonged procedures, have a high risk of oxidant stress because of the combined effects of systemic inflammation, intravascular hemolysis, and/or ischemia/reperfusion. Cyanotic children, who often have reduced antioxidant capacity, ${ }^{7}$ may be at particular risk because they experience an additional acute oxidation stress at the onset of $\mathrm{CPB}$, when the arterial saturation increases abruptly from the low levels of the patient to the high levels of the CPB prime. Such abrupt reoxygenation can cause a burst of nitric oxide, peroxynitrite, and superoxide radical release. ${ }^{8}$ Termed reoxygenation injury, this is associated with the development of postoperative myocardial dysfunction, a major cause of morbidity and mortality in this group. ${ }^{9}$ Oxidative injury to protein structure may be a hitherto unrecognized mechanism of pathology that contributes to such postoperative complications.

We therefore aimed to investigate the incidence, timing, and duration of protein oxidation damage in children undergoing CPB to determine whether such injury occurs, which children are at greatest risk, and whether there is evidence of association between protein oxidation injury and postoperative outcomes.

\section{Methods \\ Patients}

Institutional and informed consent was obtained from 24 patients undergoing $\mathrm{CPB}$ for the repair of congenital heart disease. To recruit a cyanotic and a comparable acyanotic control group, children were prospectively selected on the basis of preoperative arterial saturation less than or equal to $92 \%$ (cyanotic; $n=12$ ) or greater than or equal to $95 \%$ (acyanotic; $n=12$ ) and on estimated CPB time, such that comparable numbers were undergoing both short ( $<120$ minutes) and prolonged $(>120$ minutes) CPB in each group. Saturation was recorded with subjects resting comfortably in room air before anesthesia. Children were also selected such that the age, weight, and body surface area distribution was similar between the 2 groups (Table 1).

\section{CPB}

After systemic heparinization, CPB was conducted with bicaval and aortic cannulation and followed routine institutional protocols designed to minimize the oxidant stress of $\mathrm{CPB} .{ }^{9}$ These prescribe blood prime oxygenation of $21 \%$ in cyanotic children and management of arterial $\mathrm{Po}_{2}$ between 90 and $120 \mathrm{~mm} \mathrm{Hg}$ in cyanotic or between 100 and $150 \mathrm{~mm} \mathrm{Hg}$ in acyanotic children throughout CPB. All blood used for priming or added to the circuit was leukofiltered by using Terumo Immuguard III-RC leukofilter (Terumo Corp, Tokyo, Japan). Bypass temperatures were maintained at $32^{\circ} \mathrm{C}$, except in patients undergoing prolonged $\mathrm{CPB}$, in whom they were decreased to $28^{\circ} \mathrm{C}$. Myocardial protection was afforded with 20-minutely antegrade blood cardioplegia. Modified ultrafiltration was performed routinely in all cases.

\section{Blood Samples}

A total of 1 to $2 \mathrm{~mL}$ of heparinized arterial blood was collected before surgery and at 3, 30, 60, 120, 180, and 360 minutes after the institution of CPB from either the peripheral arterial line (before and after $\mathrm{CPB}$ ) or the arterial pump circuit when on CPB. Samples were immediately centrifuged. The plasma was snap-frozen in liquid nitrogen and stored at $-60^{\circ} \mathrm{C}$. Samples were analyzed in batches by an operator blinded to patient identity.

\section{High-Performance Liquid Chromatography Analysis} Samples were processed as described previously ${ }^{10}$ to isolate proteins and release the free amino acids (oxidized and parent), and then they were analyzed in triplicate by using an LC-10A highperformance liquid chromatography system (Shimadzu, South Rydalmere, NSW, Australia) equipped with a column oven (Waters, Milford, Mass; $30^{\circ} \mathrm{C}$ ) and UV and fluorescence detectors (Shimadzu). The native tyrosine content of the protein sample was quantified by its absorbance at $280 \mathrm{~nm}$. The DOPA content was detected by fluorescence as reported previously. ${ }^{10}$ Elution positions were defined on the basis of standards, and identities were confirmed by UV and fluorescence spectra. Ratios of the absolute concentrations of DOPA/native tyrosine content were calculated for each protein sample and are expressed in millimoles of product per mole of parent amino acid (Table 1).

\section{Postoperative Outcomes}

Patients were managed after surgery by intensive care staff, who were blinded to the results of high-performance liquid chromatography analysis. They documented days of intensive care, ventilatory and inotropic support, and presence or absence of atrial arrhythmias. Each patient's maximum inotrope requirement was estimated by calculating an inotrope score. This was based on a prospectively defined 1 to 3 graduation for the maximum dose of each inotrope, where 1 indicated 1-5, 2 indicated 5-10, and 3 indicated 10 or more micrograms per kilogram per minute of dopamine and 1 indicated $0.01-0.1,2$ indicated $0.1-0.2$, and 3 indicated 0.2 or more micrograms per kilogram per minute of adrenaline, noradrenaline, or milrinone. Scores for each inotrope were added to achieve the total score.

\section{Data Handling}

Normally distributed data are presented as mean and standard deviation; otherwise, medians and ranges are provided. Statistical analysis was performed with SPSS analytical software version 11.5.1 (SPSS Inc, Chicago, Ill). Differences between groups were analyzed with 2-tailed Student $t$ tests or nonparametric 2-independent sample tests as appropriate and multivariate analysis by repeated-measures general linear model. Differences within groups were analyzed with paired 2-tailed Student $t$ tests and a repeated-measures general linear model. Missing data (italics in Table 1) occurred because of a change of protocol (addition of the 30-minute sample) after the first 3 patients and because of sample collection or handling errors $(n=2)$. For repeated-measures analysis, these data were calculated by carrying the last result forward and adding the mean change across the group. Linear and multiple regression were used to explore associations between continuous variables, which included those shown in Table 1, plus weight, minimum temperature, DOPA/tyrosine at 60 and 360 minutes, and the mea- 


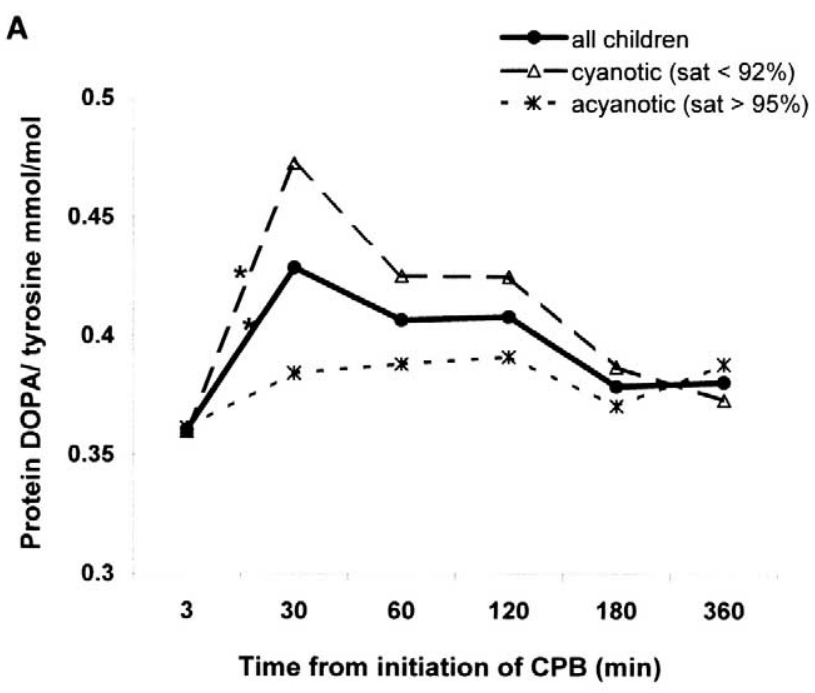

B

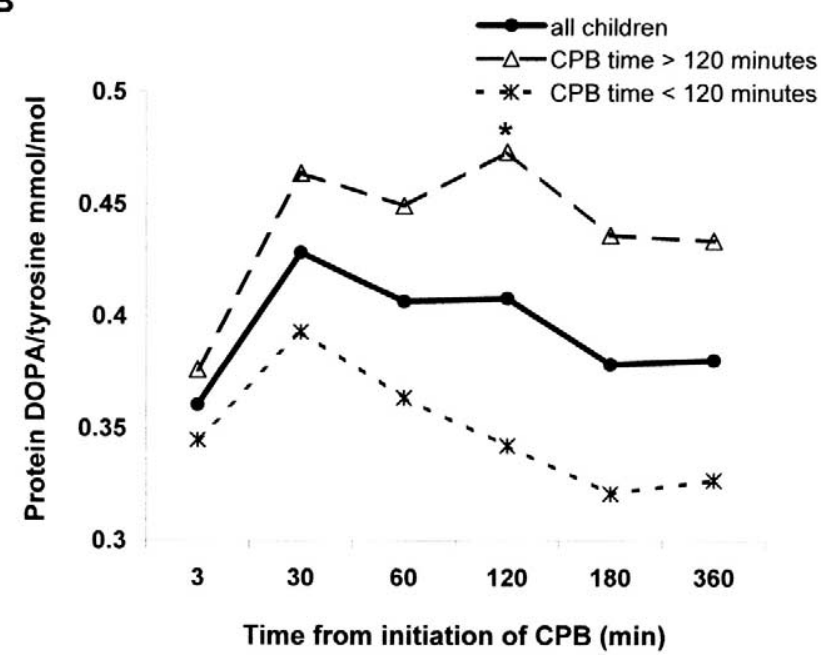

Figure 1. Mean DOPA/tyrosine levels at discrete times after institution of cardiopulmonary bypass (CPB) in children showing $A$, differences between cyanotic and acyanotic children $\left({ }^{*}\right.$ withingroup significance of $\boldsymbol{P}<.05$ ) and $\mathrm{B}$, differences between children undergoing greater than or less than 120 minutes of CPB (*between-group significance of $P<.05$ ).

sures of postoperative outcome mentioned previously. When outcome was explored by using "day" variables, children who died were assigned the maximum plus 1 day to reflect worse outcome. Receiver operating characteristic (ROC) curves were used to determine which variables had the greatest predictive values for outcome and postoperative complications.

\section{Results}

Patient demographics and surgical procedures are listed in Table 1. Fourteen patients were male, and 10 were female. The median age was 19 months (range, 2 weeks to 14.5

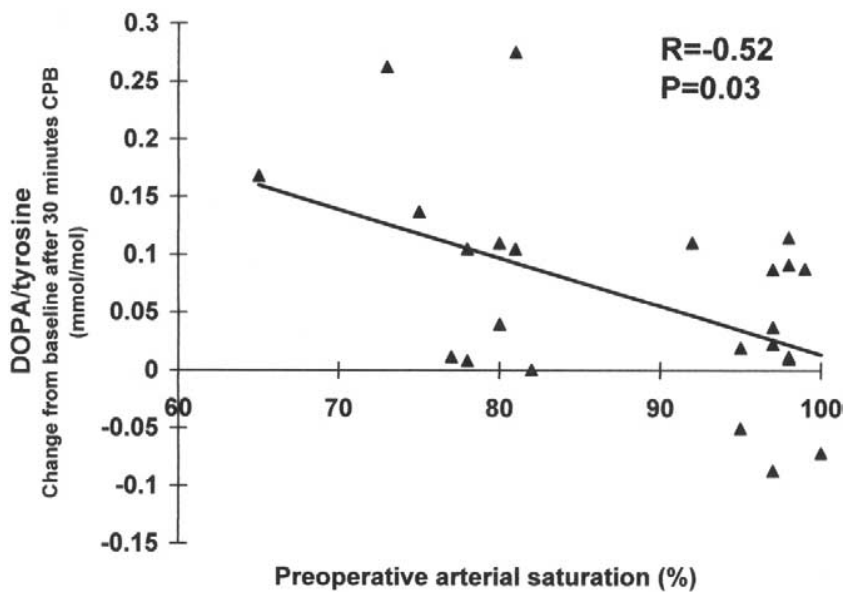

Figure 2. Correlation between preoperative arterial saturation and the magnitude of change in DOPA/tyrosine levels after 30 minutes of cardiopulmonary bypass.

years). The mean preoperative arterial saturation in the acyanotic group was $97 \%$ (SD, 1\%; patients 1-12, Table 1) versus $79 \%(\mathrm{SD}, 6 \%)$ in the cyanotic group $(P<.001$; patients 13-24, Table 1). Age, weight, body surface area, priming volume, CPB and aortic root crossclamp times (XCT), and minimum temperatures were not significantly different between the cyanotic and acyanotic groups.

The median CPB time in the short CPB group was 67.5 minutes (interquartile range, 54-102 minutes; patients 1-7 and 13-17, Table 1) versus 155 minutes (interquartile range, 133-189 minutes) in the long CPB group $(P<.001$; patients 8-12 and 18-24, Table 1). Other than expected differences in XCT (68 minutes [SD, 52 minutes] vs 27 minutes [SD, 27 minutes]; $P=.04$ ) and minimum CPB temperatures $\left(26.3^{\circ} \mathrm{C}\right.$ vs $\left.32.8^{\circ} \mathrm{C} ; P<.001\right)$, there were no significant differences in demographic or preoperative variables (including preoperative arterial saturation) between children in the long and short CPB groups.

\section{Protein DOPA/Tyrosine Ratios}

The average preoperative DOPA/tyrosine ratio in the bulk plasma protein fraction was $0.33 \mathrm{mmol} / \mathrm{mol}(\mathrm{SD}, 0.13$ $\mathrm{mmol} / \mathrm{mol}$ ) across the entire cohort (Table 1 and Figure 1). Elevation to $0.36 \mathrm{mmol} / \mathrm{mol}(\mathrm{SD}, 0.13 \mathrm{mmol} / \mathrm{mol} ; P=.03$ ) occurred 3 minutes after the institution of $\mathrm{CPB}$, subsequent to mixing with prime blood. Repeated-measures analysis demonstrated that a further increase from the 3-minute (baseline) level occurred over time $(P=.005)$. The most notable increase in the DOPA/tyrosine ratio (to $0.43 \mathrm{mmol} /$ mol [SD, $0.13 \mathrm{mmol} / \mathrm{mol}$ ]; $P=.001$ ) occurred between 3 and 30 minutes (solid line in Figure 1). When added to the model, preoperative arterial saturation and $\mathrm{CPB}$ time were both identified as factors with potential independent predic- 
TABLE 2. Correlation between protein DOPA/tyrosine values and postoperative outcome

\begin{tabular}{lcclccc}
\hline & \multicolumn{2}{c}{$\begin{array}{c}\text { 120-min DOPA/ } \\
\text { tyrosine }\end{array}$} & & \multicolumn{2}{c}{$\begin{array}{c}\text { 180-min DOPA/ } \\
\text { tyrosine }\end{array}$} \\
\cline { 2 - 3 } \cline { 6 - 7 } Variable & $\boldsymbol{P}$ value & $\boldsymbol{R}$ value & & $\boldsymbol{P}$ value & $\boldsymbol{R}$ value \\
\hline Days in ICU & .003 & 0.6 & & .003 & 0.6 \\
Days ventilated & $<.001$ & 0.7 & & .001 & 0.6 \\
Days on inotropic support & $<.001$ & 0.6 & & .003 & 0.6 \\
Inotropic score & $<.001$ & 0.6 & & .002 & 0.6 \\
\hline
\end{tabular}

$D O P A, 3,4-D i h y d r o x y p h e n y l a l a n i n e ; ~ I C U$, intensive care unit.

tive effects. Saturation group independently predicted the increase in the protein DOPA/tyrosine ratio between 3 and 30 minutes $(P=.02)$. The independent predictive effect of CPB time approached significance $(P=.06)$. These were therefore examined in closer detail. No other preoperative or intraoperative variables, including age or bypass temperature, demonstrated independent predictive effects. XCT correlated with the 120-minute DOPA/tyrosine ratio $(R=0.45$; $P=.03)$ with univariate, but not multivariate, linear regression analysis, because of colinearity with CPB time.

\section{Effect of Preoperative Arterial Saturation}

The preoperative protein DOPA/tyrosine ratio was similar in the cyanotic $(0.33 \mathrm{mmol} / \mathrm{mol} ; \mathrm{SD}, 0.12 \mathrm{mmol} / \mathrm{mol})$ and acyanotic $(0.34 \mathrm{mmol} / \mathrm{mol} ; \mathrm{SD}, 0.15 \mathrm{mmol} / \mathrm{mol})$ children. Repeated-measures analysis revealed a significant increase in the ratio over time in cyanotic but not in acyanotic children: the most prominent effect was an increase (to 0.47 $\mathrm{mmol} / \mathrm{mol}[\mathrm{SD}, 0.1 \mathrm{mmol} / \mathrm{mol}] ; P=.001)$ at 30 minutes after the institution of CPB in cyanotic children (dashed line Figure 1, A). The increase in the protein DOPA/tyrosine ratio between baseline and 30 minutes correlated inversely with the preoperative arterial saturation $(R=-0.52 ; P=$ .03; Figure 2).

\section{Effect of CPB Time}

The mean protein DOPA/tyrosine ratio was higher at 120 minutes $(0.47 \mathrm{mmol} / \mathrm{mol}$ [SD, $0.15 \mathrm{mmol} / \mathrm{mol}]$ vs 0.34 $\mathrm{mmol} / \mathrm{mol}$ [SD, $0.13 \mathrm{mmol} / \mathrm{mol}] ; P=.04)$ and 180 minutes $(0.44 \mathrm{mmol} / \mathrm{mol}[\mathrm{SD}, 0.17 \mathrm{mmol} / \mathrm{mol}]$ vs 0.32 $\mathrm{mmol} / \mathrm{mol}[\mathrm{SD}, 0.11 \mathrm{mmol} / \mathrm{mol}] ; P=.04)$ after the initiation of CPB in children who remained on bypass (ie, those in the prolonged $\mathrm{CPB}$ group) than in children who had ceased CPB (ie, those in the short CPB group). The mean DOPA/tyrosine ratios increased within 30 minutes of commencing CPB in children undergoing prolonged CPB $(P=$ $.01)$ and remained increased above baseline throughout and up to 6 hours after the initiation of CPB (short-dashed line in Figure 1, B). In contrast, protein DOPA/tyrosine ratios rapidly returned to baseline levels in children who under-

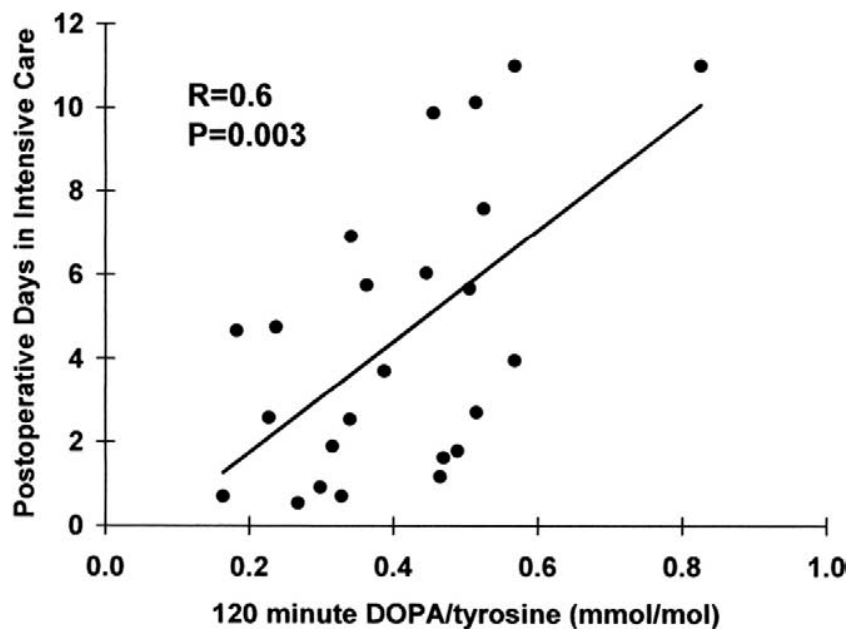

Figure 3. Correlation between protein DOPA/tyrosine ratio at 120 minutes after the initiation of CPB and the number of postoperative days in intensive care.

went short $(<120$-minute) procedures (long-dashed line in Figure 1, B).

The sustained increase in protein DOPA/tyrosine ratios seen in children undergoing prolonged CPB occurred predominantly in cyanotic as opposed to acyanotic children. Mean protein DOPA/tyrosine ratios were increased from baseline $(0.31 \mathrm{mmol} / \mathrm{mol} ; \mathrm{SD}, 0.10 \mathrm{mmol} / \mathrm{mol})$ at $120 \mathrm{~min}-$ utes $(0.44 \mathrm{mmol} / \mathrm{mol} ; \mathrm{SD}, 0.12 \mathrm{mmol} / \mathrm{mol} ; P=.007)$ and 180 minutes $(0.40 \mathrm{mmol} / \mathrm{mol} ; \mathrm{SD}, 0.14 \mathrm{mmol} / \mathrm{mol} ; P=.01)$ in cyanotic but not in acyanotic children undergoing more than 120 minutes of CPB. However, the highest recorded protein DOPA/tyrosine ratio $(0.82 \mathrm{mmol} / \mathrm{mol})$ and the greatest increase from baseline $(0.32 \mathrm{mmol} / \mathrm{mol})$ occurred after 120 minutes of CPB and prolonged aortic root crossclamping in an acyanotic child with neonatal Marfan syndrome.

\section{Postoperative Outcomes}

Two children in the prolonged CPB group died in the early postoperative period as a result of intractable cardiac failure. These children had the highest protein DOPA/tyrosine ratios of all at both 120 and 180 minutes (Table 1). There was no correlation between 30- and 60-minute DOPA/tyrosine ratios and postoperative outcome. However, there was strong positive correlation between both the 120- and 180minute protein DOPA/tyrosine ratios and all measures of postoperative outcome (Table 2 and Figure 3). Overall, however, because of colinearity, CPB time was identified as the single most important predictor of postoperative outcome on multivariate analysis, although the 120-minute DOPA/tyrosine level contributed an independent effect to the model for days of postoperative ventilation $(P=.03)$. 
ROC curve analysis similarly identified the CPB time as the variable with the greatest predictive value for poor postoperative outcome (defined as $>5$ days on inotropic support or death), with an area under the curve of 0.94. However, the 180- and 120-minute DOPA/tyrosine levels also displayed high predictive values (area under the curve of 0.84 and 0.77 , respectively) and exceeded the predictive value of all other variables, including XCT. A DOPA/tyrosine ratio of $0.42 \mathrm{mmol} / \mathrm{mol}$ at 180 minutes predicted poor outcome with maximum sensitivity (83\%) and specificity $(78 \%)$.

\section{Arrhythmias}

Nine of 24 children had postoperative atrial arrhythmias (Table 1). This included 5 cases of junctional ectopic tachycardia, 3 of nodal or junctional bradyarrhythmia, and 1 of second-degree heart block. This group demonstrated increased postoperative support requirements according to days in intensive care (6.6 vs $3.1 ; P=.008)$ and had increased 120 -minute DOPA/tyrosine ratios $(5.0 \mathrm{mmol} / \mathrm{mol}$ [SD, $0.16 \mathrm{mmol} / \mathrm{mol}$ ] vs $3.5 \mathrm{mmol} / \mathrm{mol}[\mathrm{SD}, 0.11 \mathrm{mmol} /$ mol]; $P=.01$ ) despite not having longer CPB or XCT than children who did not have arrhythmias. ROC curve analysis identified the 120-minute protein DOPA/tyrosine ratio as the variable with the greatest predictive value for postoperative arrhythmia (area under the curve, 0.82). A value of $0.45 \mathrm{mmol} / \mathrm{mol}$ predicted postoperative arrhythmia with maximum sensitivity (78\%) and specificity (73\%).

\section{Discussion}

In this study, we have demonstrated that oxidation-induced changes to the structure of plasma proteins occur acutely during CPB in children. Children with preoperative arterial desaturation and those undergoing prolonged CPB are most susceptible. Furthermore, if present beyond 120 minutes of CPB, such oxidation-induced protein injury seems to be associated with measures of postoperative morbidity.

The importance of the proteome and the susceptibility of proteins to oxidation by radicals are increasingly recognized as mechanisms of pathology in cardiovascular biology and medicine. ${ }^{11}$ Protein injury due to oxidation impairs critical biological mechanisms such as cell morphology, microtubule organization, and contractile function and has been implicated in the development of chronic conditions such as vasculopathy in diabetics and smokers. ${ }^{11-13}$ Oxidative impairment of myofibrillar creatine kinase, a key protein important in the control of myocyte contractility, has been implicated in the development of chronic heart failure due to doxorubicin toxicity and chronic atrial arrhythmias. ${ }^{13,14}$ Although currently unexplored, such findings suggest that protein function may be similarly compromised under conditions of acute oxidation stress, such as occur during CPB, and thereby might contribute to postoperative morbidity.

The acute oxidative stress of CPB is well documented. It is principally triggered by exposure of the circulating blood to the nonphysiologic surfaces of the bypass circuit: this results in activation of regulatory and inflammatory cascades. ${ }^{15}$ Neutrophils are activated to release cytotoxic enzymes, including myeloperoxidase, and generate superoxide radicals and hydrogen peroxide. ${ }^{16}$ Reperfusion of the heart and lungs after hypothermic ischemia is also a trigger for oxygen radical production, ${ }^{17,18}$ as is abrupt elevation of arterial saturation at the onset of CPB in cyanotic children. Although several strategies have been developed to reduce the oxidative stress of $\mathrm{CPB}$, including improving the biocompatibility of $\mathrm{CPB}$ circuits, leukofiltration, and controlled reoxygenation in cyanotic patients, ${ }^{19,20}$ there are practical limitations to the application of such techniques, such that the oxidative stress cannot be negated completely. In children, for example, although all donor blood added to the circuit can be washed and leukofiltered, complete systemic leukofiltration is not readily achieved because of the lack of a suitably effective leukofilter for pediatric use. Also, controlled reoxygenation cannot completely prevent an abrupt increase in arterial saturation at the onset of CPB in cyanotic children because the efficiency of modern oxygenators results in a blood prime $\mathrm{Po}_{2}$ of 140 to $155 \mathrm{~mm} \mathrm{Hg}$ even when circulated in $21 \%$ oxygen (air). For these reasons, the risk of oxidation-induced injury to proteins during pediatric CPB remains unknown.

In this study, we examined the incidence of oxidative protein injury by detecting increasing levels of proteinbound DOPA relative to native tyrosine in the bulk plasma protein fraction. Tyrosine is one of the most highly reactive amino acid side chains $\left(1.3 \mathrm{k} \times 10^{10} \mathrm{dm}^{3} \cdot \mathrm{mol}^{-1} \cdot \mathrm{s}^{-1}\right.$ for hydroxyl radicals). ${ }^{21}$ In the presence of radical species, it is hydroxylated to DOPA. The detection of increasing levels of protein-bound DOPA relative to native tyrosine is well established as a sensitive and specific method of both detecting oxidative stress and quantifying oxidative damage to bulk proteins. This has been extensively validated both in vitro and in vivo. ${ }^{1,2,6,10-12,21}$ Previous studies have demonstrated that protein-bound DOPA formation not only is indicative of oxidative protein damage, but also induces protein cross-linking, impairs protein folding, induces aggregation, and causes increased protein turnover, thus resulting in impairment of both protein and cellular function. ${ }^{1,2}$

Our results have shown that, despite leukofiltration and controlled reoxygenation as outlined previously, acute oxidative protein injury does occur during pediatric $\mathrm{CPB}$, in cyanotic children, and in children undergoing prolonged CPB.

The finding of an abrupt early increase in the protein DOPA/tyrosine ratio in cyanotic, but not in acyanotic, chil- 
dren supports our hypothesis that cyanotic children are at greater risk of oxidation-induced protein injury. This is possibly due to a combination of their lower antioxidant reserves and the additional oxidation stress associated with abrupt reoxygenation.

Our encouraging results suggest that a brief oxidative insult to proteins may be tolerated without significant detrimental effects, because increased oxidized protein levels in the first 60 minutes of CPB decreased quickly to baseline in cyanotic children who underwent less than 120 minutes of CPB and were not associated with poor postoperative outcome.

However, our results suggest that prolonged ( $>120$ minutes) CPB-related oxidative insult may not be so well tolerated. The strong correlation between oxidized protein levels and measures of postoperative outcome in children undergoing more than 120 minutes of CPB indicates that oxidative impairment of protein function cannot be excluded as a mechanism contributing to postoperative complications in these cases. Nevertheless, we cannot assume a causal link on the basis of the current data. Much of this association may be explained by the colinearity between protein DOPA/tyrosine ratios and CPB time, which is a well-known predictor of outcome. However, the pathophysiologic mechanisms by which prolonged CPB results in poor outcome remain incompletely defined. The greater predictive value of the 120-minute protein DOPA/tyrosine ratio (compared with $\mathrm{CPB}$ time) for postoperative atrial arrhythmia and the independent association with the need for prolonged postoperative ventilation are consistent with the hypothesis that oxidative impairment of protein function may play a contributing role.

The early increase of protein DOPA/tyrosine ratios in children destined to undergo prolonged CPB procedures, coupled with the finding of a profound increase in protein DOPA/tyrosine ratios in an acyanotic child with Marfan syndrome, suggests that other unmeasured factors, such as preoperative cardiac stress or genetic differences in response to oxidative stress, may also play a contributing role. This will require further study.

\section{Limitations}

There is obvious heterogeneity in the diagnoses of patients enrolled in this study. This is because we believed that preoperative arterial saturation and $\mathrm{CPB}$ time were more likely than anatomic diagnosis to affect oxidized protein levels, and patients were selected accordingly to form a cyanotic and corresponding acyanotic control group on the basis of CPB time rather than anatomic diagnosis. The relatively small numbers of patients in this initial study are also insufficient to assess the effect of protein oxidation on mortality.
This is the first study to confirm that oxidative modification and injury of the proteome occurs during pediatric $\mathrm{CPB}$. These initial results document the incidence and timing of oxidant protein damage and a potential association with adverse postoperative outcomes in children. This information allows us to target particular at-risk groups in whom oxidant injury of key target proteins can be explored, to elucidate the pathophysiologic role of protein oxidation in the development of morbidity and mortality after pediatric $\mathrm{CPB}$.

We gratefully acknowledge the assistance of Shanlin Fu and HongJie Wang, formerly of the Cell Biology Group, The Heart Research Institute, Sydney.

\section{References}

1. Gieseg SP, Simpson JA, Charlton TS, Duncan MW, Dean RT. Protein-bound 3,4-dihydroxyphenylalanine is a major reductant formed during hydroxyl radical damage to proteins. Biochemistry. 1993;32:4780-6.

2. Dean RT, Fu S, Stocker R, et al. Biochemistry and pathology of radical-mediated protein oxidation. Biochem J. 1997;324:1-18.

3. Chevion M, Berenshtein E, Stadtman ER. Human studies related to protein oxidation: protein carbonyl content as a marker of damage. Free Radic Res. 2000;33(suppl):S99-108.

4. Mihm MJ, Coyle CM, Schanbacher BL, et al. Peroxynitrite induced nitration and inactivation of myofibrillar creatine kinase in experimental heart failure. Cardiovasc Res. 2001;49:798-807.

5. Patel RP, Moellering D, Murphy-Ullrich J, et al. Cell signalling by reactive nitrogen and oxygen species in atherosclerosis. Free Radic Biol Med. 2000;28:1780-94.

6. Morin B, Davies MJ, Dean RT. The protein oxidation product 3,4 dihydroxyphenylalanine (DOPA) mediates oxidative DNA damage. Biochem J. 1998;330:1059-67.

7. Teoh KH, Mickle ADG, Weisel RD, et al. Effect of oxygen tension and cardiovascular operations on the myocardial antioxidant enzyme activities in patients with tetralogy of Fallot and aorta-coronary bypass. J Thorac Cardiovasc Surg. 1992;104:159-64.

8. Ihnken K, Morita K, Buckberg GD, et al. Studies of hypoxemic/ reoxygenation injury without aortic clamping: II. Evidence for reoxygenation damage. J Thorac Cardiovasc Surg. 1995;110:891901.

9. Allen BS, Rahman S, Ilbawi MN, et al. Detrimental effects of cardiopulmonary bypass in cyanotic infants: preventing the reoxygenation injury. Ann Thorac Surg. 1997;64:1381-8.

10. Davies MJ, Fu S, Wang H, et al. Stable markers of oxidant damage to proteins and their application in the study of human disease. Free Radic Biol Med. 1999;27:1151-63.

11. Loscalzo J. Proteomics in cardiovascular biology and medicine. Circulation. 2003;108:380-3.

12. Eiserich JP, Estevez AG, Bamberg TV, et al. Microtubule dysfunction by posttranslational nitrotyrosination of alpha-tubulin: a nitric oxidedependent mechanism of cellular injury. Proc Natl Acad Sci USA. 1999;96:6365-70.

13. Mihm MJ, Yu F, Weinstein DM, et al. Intracellular distribution of peroxynitrite during doxorubicin cardiomyopathy: evidence for selective impairment of myofibrillar creatine kinase. $\mathrm{Br} J$ Pharmacol. 2002;135:581-8.

14. Mihm MJ, Yu F, Carnes CA, et al. Impaired myofibrillar energetics and oxidative injury during human atrial fibrillation. Circulation. 2001;104:174-80.

15. Royston D, Fleming JS, Desai JB, et al. Increased production of peroxidation products associated with cardiac operations. J Cardiovasc Surg. 1986;91:759-66.

16. Asimakopoulos G, Taylor K. Effects of cardiopulmonary bypass on leukocytes and endothelial adhesion molecules. Ann Thorac Surg. 1998;66:2135-44. 
17. Kawata H, Sawatari K, Mayer JE Jr. Evidence for the role of neutrophils in reperfusion injury after cold cardioplegic ischaemia in neonatal lambs. J Thorac Cardiovasc Surg. 1992;103:908-18.

18. Boyle EM Jr, Pohlman TH, Cornejo CJ, et al. Ischemia-reperfusion injury. Ann Thorac Surg. 1997;64:S24-30.

19. Morita K, Ihnken K, Buckberg GD. Studies of hypoxemic/reoxygenation injury: with aortic clamping. XII. Delay of cardiac reoxygenation damage in the presence of cyanosis: a new concept of controlled cardiac reoxygenation. J Thorac Cardiovasc Surg. 1995;110:1265-73.

20. Bolling KS, Halldorsson A, Allen BS, et al. Prevention of the hypoxic reoxygenation injury with the use of a leukocyte depleting filter. J Thorac Cardiovasc Surg. 1997;113:1081-90.

21. Solar S, Solar W, Getoff N. Reactivity of $\mathrm{OH}$ with tyrosine in aqueous solution studied by pulse radiolysis. J Phys Chem. 1984; 88:2091-5.

\section{ON THE MOVE?}

\section{Send us your new address at least six weeks ahead}

Don't miss a single issue of the journal! To ensure prompt service when you change your address, please photocopy and complete the form below.

Please send your change of address notification at least six weeks before your move to ensure continued service. We regret we cannot guarantee replacement of issues missed due to late notification.

\section{JOURNAL TITLE:}

Fill in the title of the journal here.

\section{OLD ADDRESS:}

Affix the address label from a recent issue of the journal here.

\section{NEW ADDRESS:}

Clearly print your new address here.

Name

Address

City/State/ZIP
COPY AND MAIL THIS FORM TO:

Elsevier Inc.

Subscription Customer Service

6277 Sea Harbor Dr

Orlando, FL 32887
OR FAX TO:

407-363-9661

OR E-mail:

elspcs@elsevier.com
OR PHONE:

800-654-2452

Outside the U.S., call

407-345-4000 